\title{
Who's Watching? A feminist urban video installation
}

\author{
Lydia Smolin \\ University of Applied Sciences Europe \\ Berlin, Germany \\ lydiasmolin@hotmail.com
}

\author{
Katrin Wolf \\ Hamburg University of Applied Sciences \\ Hamburg, Germany \\ katrin.wolf@haw-hamburg.de
}

\section{INTRODUCTION}

This paper explores the idea of an individual's sense of awareness when moving through a specific space. The work entitled: Who's Watching? is a feminist artwork, an audio/visual, site-specific experience, meant to prompt the individual to acknowledge their true surroundings. This project is intended to foster a discussion on how, in the area of visual arts, the application of performance art and film can increase a discourse on feminism by creating both physically and conceptually interesting and thought provoking perspectives.

Looking at society today, there are two types of gaze, the male gaze and the female gaze. According to John Berger, the male and female gazes can be simplified so that men act and women appear (Berger 2008). The man's sole purpose is to give an impression of power to others. The female gaze, however, is not necessarily in her control. A woman's presence is apparent in everything she does, how she carries herself, her voice, her gestures, her clothes and her chosen surroundings.

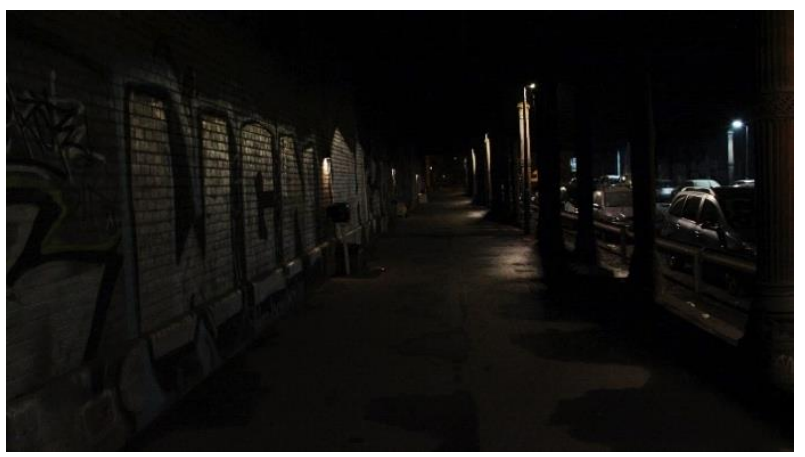

Figure 1: The underpass with three TV devices and surveillance cameras.

Who's Watching? (https://vimeo.com/240142153) is a thought provoking urban video installation focusing on the oppressive feeling women have of being watched. The work deals with social issues regarding public harassment (both verbal and physical), which the female population in particular is subjected to on a daily basis. In this paper, we will continue the discourse on feminist art and the potential of using the urban space to create empathy with the female perception and emotions regarding the ever-present fear of being harassed in insecure urban areas.

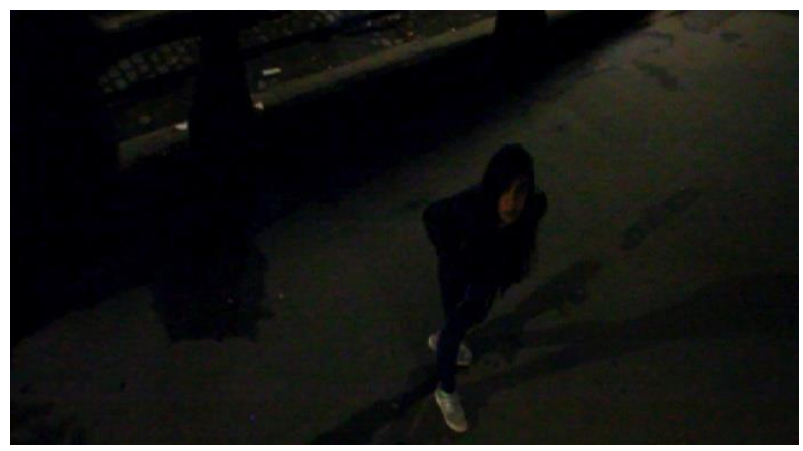

Figure 2: Surveillance camera capture of a passing female.

\section{DISCOURSE ON FEMINIST ART}

In the late 1960's the feminist movement impacted greatly on how women were seen in society. This started a dialogue that fed into many professions including the art world, which was heavily dominated by their male counterparts. These artists used media such as painting, performance art, craft and video installations to express their political opinions. Never the less feminist artists, despite this momentous time feminist artists were still not taken seriously.

Judy Chicago, one of the pioneers of feminist art, introduced in the 1970s the concept of reflecting personal narratives and political movements regarding female artists. She believes in art that "is connected to real human feeling that extends itself beyond the limits of the art world" (Jenkins 2018). 
Fast forward to 2017, almost 50 years later, a new voice is rising up with the \#MeToo viral movement in the wake of which the MET was forced to defended one of its permanent pieces for romanticising voyeurism and objectifying children: Balthus' Thérèse Dreaming (1938). This has opened up a whole new discourse (Bradshaw 2017).

In relation to these movements, it is important to look at how art and the media have engrained the idea of voyeurism into society. Whether intentional or not, people today seem to have a need to perform once a camera is pointed at them. Jordan Crandall discusses this concept which portrays both the male and female gaze as dominated by a 'scopic power', an unseen watching presence which compels us to seek validation, to secure our being and ultimately subjects us to being put in our place (Crandall 2009).

\section{POTENTIAL OF USING THE URBAN SPACE TO CREATE EMPATHY FOR FEMALES}

The installation Who's Watching? visualises the words of John Berger in an emotional and stimulating way. The gaze is important in relation to how we situate ourselves in space and position ourselves in society. In 2017, the world saw a new rise in feminism, focusing particularly on sexual misconduct and assault, calling out men in power. This issue is only gathering more momentum as it is seen to exist in more and more aspects of women's lives. Therefore, an artwork that relays this emotion to those who experience it can serve to acknowledge its legitimacy.

In order to reproduce this feeling, a specific space with particular environmental factors is necessary. For this reason, an underpass is the chosen location (Figure 1). An underpass is a good example of an urban space that nearly every woman must consider first before entering while men generally don't have this concern. It contains a limited amount of entrances and exits channelling the walker along specific pathways. Using real footage of a faceless male figure, surveillance cameras (Figure 2), analogue televisions and sound effects, this installation prompts the participants to consciously perceive their surroundings. It brings into question their personal safety and highlights their heightened sense of awareness when moving through the space.

\section{CONCLUSION}

In the area of visual arts, this paper discusses how feminist art is constantly striving for new and diverse methods of tackling the issues women face in society today. Focusing on the topic of the female gaze there is potential to obtaining empathy from our male counterparts and opening up further discussion on this perspective. Through the use of a specific urban space, such as the underpass, we can observe how a controlled environment can alter one's perception and ultimately make us truly be aware of our surroundings.

\section{REFERENCES}

Berger, J. (2008) Ways of Seeing. Penguin Books, London.

Bradshaw, P. (2017) \#MeToo has reached the art world. Don't think it's running out of steam. The Guardian, 6 December 2017.

https://www.theguardian.com/commentisfree/2017/ dec/06/metoo-art-new-york-metropolitan-museumart-balthus (retrieved 15 March 2018).

Crandall, J. (2009) Ecologies of Self-Display. Media Arts Cultures. http://pl02.donauuni.ac.at/jspui/bitstream/10002/618/1/selfdisplay1.p df (retrieved 15 March 2018).

Jenkins, S. (2018) Judy Chicago Artist Overview and Analysis. TheArtStory.org.

http://www.theartstory.org/artist-chicago-judy.htm (retrieved 15 March 2018). 